ISSN: $2455-104 X$

Volume 4,Issue 2 (July-December) 2018,40-54

Received: 28 Sep .2018 ; Accepted: 31 Oct. 2018 ; Published: 14 Nov. 2018 ; Paper ID: IJRLS-1293

\title{
MEASURE THE REACH OF SCIENTIFIC PUBLICATIONS: A SCIENTOMETRIC STUDY
}

\author{
Tamizhchelvan, $\mathbf{M}^{1}$; Gopalakrishnan, $\mathrm{S}^{\mathbf{2}}$ \\ Deputy Librarian, The Gandhigram Rural Institute, (Deemed to be University), Gandhigram - $624302^{1}$; \\ Assistant University Librarian (Retd.), Madras Institute of Technology Campus, Anna University, \\ Chromepet, Chennai - $600044^{2}$ \\ E-mail: tamizhchelvan@gmail.com ${ }^{1}$; gopallong@gmail.com ${ }^{2}$
}

\begin{abstract}
Citation frequency reflects the value of scientific publications. The cited papers were considered as Reach of the paper and uncited publications were considered as unreached publications. Measures of reach of scientific output were made using Reach percentage (RP); Reach Activity Index (RAI); Unreach/Reach Activity Index (URAI) and Unreach Activity Index (UAI). In order to identify the reach of the publications, the publications pertaining to Indian Institute of Management, Internationally renowned management institutions, were taken up for the study with the opinion that these publications were reached globally. Therefore 13 IIMs faculty research publications were taken up for the study. The data were collected from Scopus data base. 5755 publications were identified during the period of 1965 to 2018. Out of 5755 papers, 3625 (63.0\%) papers were cited where as $2130(37.0 \%)$ were not cited. It can be inferred that 63\% of the IIM's research publications were reached the users. RAI ranges between 0.65 and 1.08. IIM- Rohtak was ranked first in the reach of their publications even the number of publications were positioned seventh place in total number of papers. It is followed by IIM-C positioned second and IIM-B and IIM-A were positioned third even though the number of publications were more.
\end{abstract}

Keywords: Indian Institute of Management; Reach Activity Index; Reach Percentage; Unreach/Reach Activity Index; Unreach Activity Index

\section{INTRODUCTION}

Science and scientific communication are interrelated which influences in generating information. Among scientists and social scientists, it is widely accepted that publication of research performed in academic and governmental research institutions, is a driving force behind high technology and economic growth. It is true that research makes an important contribution to the economic growth of a nation. Such research output is used as the yardstick for measuring the quality and quantity of research done in a country or in a discipline

Citation frequency reflects the value of scientific publications and the use made of it. Citation analysis, along with peer review, has over the past three decades been increasingly used to judge the reach of the publication and quantify the importance of scientists and scientific research. Citation analysis is also the used as mean behind journal "impact factors". Indeed, the output from citation studies is often the only way that un-specialists in governments and funding bodies - or even those in different scientific disciplines - can judge the importance of a piece of scientific research.

The cited papers were considered as Reach of the paper and uncited publications were considered as unreached publications. In this study the paper reach of publications were analysed using few derived formulas. 


\section{REVIEW OF RELATED LITERATURE}

Studies related to citations of papers and authors, and especially of highly cited ones, always attract a lot of attention (VanNoorden, Maher, \& Nuzzo, 2014), one reason being that citations act as indicators in individual and institutional evaluations (Persson, 2010; Leydesdorff, 2012; Abramo, Cicero, \& D’Angelo, 2014; Bornmann, 2014). Citations, moreover, reflect relations in the network of scientific communications (Cronin, 1984).

Garg and Kumar (2014) identified that 6231 (17.5\%) Indian scientist papers out of 35,640 papers published during the period 2008-2013 remained uncited. Most of the uncited papers were published by State Agricultural Universities and the Indian Council of Agricultural Research. The highest proportion of uncited papers was in the discipline of agricultural sciences followed by multidisciplinary and mathematical sciences.

The Evidence report of Thomson Reuters has shown that there is a decrease in the percentage of papers emanating from India which do not receive citations. (Report, India).

High share of uncited publications, which include those produced by top scientists was repeatedly reported to exceed $10 \%$ of the total papers produced. Petr Heneberg (2013) analyzed the uncitedness among two independent groups of highly visible mathematicians represented by Fields medalists, researchers in physiology or medicine represented by Nobel Prize laureates. over $90 \%$ of the uncited database records of highly visible scientists has been presented in progress reports, meeting abstracts, letters to the editor, discussion, personalia, by errors of omission and commission of the Web of Science (WoS) database and of the citing documents. Only 0.9 and $0.3 \%$, of original articles and reviews were found to be uncited.

Uncitable documents was responsible for up to $30 \%$ of the total citations to the top-tier journals, with the highest values found for medical science journals (New England Journal of Medicine, JAMA, and the Lancet) and lower values found for the Science, Nature, and Cellseries journals. Self-citations to some of the top-tier journals reach values higher than the total citation counts accumulated by papers in most of the Web of Science-indexed journals. Petr Heneberg (2014).

Bathrinarayana and Tamizhchelvan (2013) studied the MEMS output of Scopus database on the growth of literature. Gopalakrishan et al (2015) identified the uncited publications in micro-electro mechanical systems (MEMS) and found that even the top author papers were also cited. Vaijinath and Shivshankar (2017) studied the author productivity patterns in the DJLIT journal upto 2015.

\section{OBJECTIVES}

The objectives of the study were

- To identify the reach of the research output to the user.

- To derive a methodology for identifying the reach of the research output

\section{MEASURE OF REACH}

Measures of reach of scientific output were made using Reach Percentage (RP); Reach Activity Index (RAI); Unreach/Reach Activity Index (URAI) and Unreach Activity Index (UAI). The method of calculation were as follows

1. Reach $\%=$ Reach output of Institution/ Total output of the institution $\ldots$. (1)

\section{Reach Activity index}


RAI $=\frac{R_{i j} / T_{i \infty}}{R_{\infty j / T 00} / T}$

Where, $R_{i j}=$ Number of cited publications for the particular Institutions a particular country

$\mathrm{T}_{\mathrm{io}}=$ Total output for the particular Institution

$\mathrm{R}_{\mathrm{oj}}=$ Total Reach output of the particular Institution

$\mathrm{T}_{\mathrm{oo}}=$ Total output of all the Institution block

\section{URAI $=$ Unreach $/$ Reach Activity Index}

The formula reads as follows:

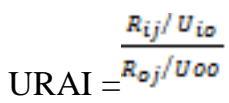

Where, $R_{i j}=$ Number of Reached publications for the particular Institutions a particular country

$\mathrm{U}_{\mathrm{io}}=$ Number of Unreached publications for the particular Institution

$\mathrm{R}_{\mathrm{oj}}=$ Total Reach output of all the Institution

$\mathrm{U}_{\mathrm{oo}}=$ Total Unreach of all the Institution block

\section{4. $\quad$ UAI = Unreach Activity Index}

The formula reads as follows:

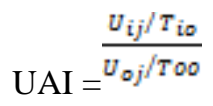

Where, $\mathrm{U}_{\mathrm{ij}}=$ Number of Unreached publications for the particular Institutions a particular country

$\mathrm{T}_{\mathrm{io}}=$ Total output for the particular Institution

$\mathrm{U}_{\mathrm{oj}}=$ Total Reach output of the particular Institution

$\mathrm{T}_{\mathrm{oo}}=$ Total output of all the Institution block

\section{Reach of IIM publications}

In order to identify the reach of the publications, the publications pertaining to Indian Institute of Management, Internationally renowned management institution, were taken up for the study with the opinion that these publications were reached globally. There exist 20 IIMs of which 6 of them were established in 2015 (Table 1). Therefore 13 IIMs faculty research publications were taken up for the study. The data were collected from Scopus data base. 5755 publications were identified during the period of 1965 to 2018.

Table 1 List of IIMs in India with short name, year of establishment, location and URL

\begin{tabular}{|l|l|l|l|l|l|}
\hline S.No & Name & $\begin{array}{l}\text { Short } \\
\text { Name }\end{array}$ & $\begin{array}{l}\text { Year of } \\
\text { Establishme } \\
\text { nt }\end{array}$ & Location & Website \\
\hline
\end{tabular}


Tamizhchelvan, M \& Gopalakrishnan, S

\begin{tabular}{|c|c|c|c|c|c|}
\hline 1 & $\begin{array}{l}\text { Indian Institute of } \\
\text { Management Calcutta }\end{array}$ & IIM-C & 1961 & $\begin{array}{l}\text { Kolkata, } \\
\text { West Bengal }\end{array}$ & iimcal.ac.in \\
\hline 2 & $\begin{array}{l}\text { Indian Institute of } \\
\text { Management Ahmedabad }\end{array}$ & IIM-A & 1961 & $\begin{array}{l}\text { Ahmedabad, } \\
\text { Gujarat }\end{array}$ & iimahd.ernet.in \\
\hline 3 & $\begin{array}{l}\text { Indian Institute } \\
\text { Management Bangalore }\end{array}$ & IIM-B & 1973 & $\begin{array}{l}\text { Bangalore, } \\
\text { Karnataka }\end{array}$ & iimb.ernet.in \\
\hline 4 & $\begin{array}{l}\text { Indian Institute of } \\
\text { Management Lucknow }\end{array}$ & IIM-L & 1984 & $\begin{array}{l}\text { Lucknow, } \\
\text { Uttar Pradesh }\end{array}$ & iiml.ac.in \\
\hline 5 & $\begin{array}{l}\text { Indian Institute } \\
\text { Management Kozhikode }\end{array}$ & IIM-K & 1996 & $\begin{array}{l}\text { Kozhikode, } \\
\text { Kerala }\end{array}$ & $\underline{\text { imk.ac.in }}$ \\
\hline 6 & $\begin{array}{l}\text { Indian Institute } \quad \text { of } \\
\text { Management Indore }\end{array}$ & IIM-I & 1996 & $\begin{array}{l}\text { Indore, } \\
\text { Madhya Pradesh }\end{array}$ & iimidr.ac.in \\
\hline 7 & $\begin{array}{l}\text { Indian Institute } \\
\text { Management Shillong }\end{array}$ & IIM-S & 2007 & $\begin{array}{l}\text { Shillong, } \\
\text { Meghalaya }\end{array}$ & iimshillong.in \\
\hline 8 & $\begin{array}{l}\text { Indian Institute } \quad \text { of } \\
\text { Management Rohtak }\end{array}$ & IIM-Rohtak & 2010 & $\begin{array}{l}\text { Rohtak, } \\
\text { Haryana }\end{array}$ & iimrohtak.ac.in \\
\hline 9 & $\begin{array}{l}\text { Indian Institute of } \\
\text { Management Ranchi }\end{array}$ & IIM-R & 2010 & $\begin{array}{l}\text { Ranchi, } \\
\text { Jharkhand }\end{array}$ & iimranchi.ac.in \\
\hline 10 & $\begin{array}{l}\text { Indian Institute } \\
\text { Management Raipur }\end{array}$ & IIM-Raipur & 2010 & $\begin{array}{l}\text { Raipur, } \\
\text { Chhattisgarh }\end{array}$ & iimraipur.ac.in \\
\hline 11 & $\begin{array}{l}\text { Indian Institute } \\
\text { Management Trichy }\end{array}$ & IIM-T & 2011 & $\begin{array}{l}\text { Trichy, } \\
\text { Tamil Nadu }\end{array}$ & iimtrichy.ac.in \\
\hline 12 & $\begin{array}{l}\text { Indian } \quad \text { Institute } \\
\text { Management Udaipur }\end{array}$ & IIM-U & 2011 & $\begin{array}{l}\text { Udaipur, } \\
\text { Rajasthan }\end{array}$ & iimu.ac.in \\
\hline 13 & $\begin{array}{l}\text { Indian Institute } \quad \text { of } \\
\text { Management Kashipur }\end{array}$ & $\begin{array}{l}\text { IIM- } \\
\text { Kashipur }\end{array}$ & 2011 & $\begin{array}{l}\text { Kashipur, } \\
\text { Uttarakhand }\end{array}$ & iimkashipur.ac.in \\
\hline 14 & $\begin{array}{l}\text { Indian Institute of } \\
\text { Management Nagpur }\end{array}$ & IIM-N & 2015 & $\begin{array}{l}\text { Nagpur, } \\
\text { Maharashtra }\end{array}$ & iimnagpur.ac.in \\
\hline 15 & $\begin{array}{ll}\text { Indian Institute } & \text { of } \\
\text { Management Bodh Gaya } & \end{array}$ & IIM-BG & 2015 & Bodh Gaya, Bihar & www.iimbg.ac.in \\
\hline 16 & $\begin{array}{l}\text { Indian Institute of } \\
\text { Management Visakhapatnam }\end{array}$ & IIM-V & 2015 & $\begin{array}{l}\text { Visakhapatnam, } \\
\text { Andhra Pradesh }\end{array}$ & $\underline{\text { iimv.ac.in }}$ \\
\hline 17 & $\begin{array}{l}\text { Indian Institute } \\
\text { Management Amritsar }\end{array}$ & $\begin{array}{l}\text { IIM } \\
\text { Amritsar }\end{array}$ & 2015 & $\underline{\text { Amritsar, Punjab }}$ & iimamritsar.ac.in \\
\hline
\end{tabular}


MEASURE THE REACH OF SCIENTIFIC PUBLICATIONS: A SCIENTOMETRIC STUDY

\begin{tabular}{|c|c|c|c|c|c|}
\hline 18 & $\begin{array}{l}\text { Indian Institute of } \\
\text { Management, Sambalpur }\end{array}$ & $\begin{array}{l}\text { IIM } \\
\text { Sambalpur }\end{array}$ & 2015 & $\begin{array}{l}\text { Sambalpur, } \\
\text { Odisha }\end{array}$ & $\underline{\text { iimsambalpur.ac.i }}$ \\
\hline 19 & $\begin{array}{l}\text { Indian Institute } \\
\text { Management, Sirmaur }\end{array}$ & $\begin{array}{l}\text { IIM } \\
\text { Sirmaur }\end{array}$ & 2015 & $\frac{\text { Sirmaur district, }}{\text { Himachal Pradesh }}$ & $\begin{array}{l}\text { http://www.iimsirma } \\
\text { ur.ac.in/ }\end{array}$ \\
\hline 20 & $\begin{array}{l}\text { Indian Institute } \quad \text { of } \\
\text { Management, Jammu }\end{array}$ & IIMJ & 2016 & Jammu & $\begin{array}{l}\text { http://www.iimj.ac.i } \\
\text { n/ }\end{array}$ \\
\hline
\end{tabular}

Reach of the publications identified based on the citation. Therefore citation analysis of 5755 papers thus taken up for study has been carried out and the same has been shown in table 2 .

\section{Table 2 Cited/uncited}

\begin{tabular}{|l|l|l|l|l|}
\hline S.No. & Cited/Uncited & Papers & Percent & $\begin{array}{l}\text { Cumulative } \\
\text { Percent }\end{array}$ \\
\hline 1 & Cited & 3625 & 63.0 & 63.0 \\
\hline 2 & Uncited & 2130 & 37.0 & 100.0 \\
\hline & Total & $\mathbf{5 7 5 5}$ & $\mathbf{1 0 0 . 0}$ & \\
\hline
\end{tabular}

Out of 5755 papers, $3625(63.0 \%)$ papers were cited where as $2130(37.0 \%)$ were not cited. It can be inferred that $63 \%$ of the IIM's research publications were reached the users. The study has further been extended to identify the 13 IIM's publications that has reached the users were shown in Table 2. The formula used for calculating the Reached \% were shown in (1) above. Similarly RAI, URAI and UAI were calculated using the formula in (2), (3) and (4) above. The ranks were assigned based on Reach \%, RAI, URAI and UAI. The number of publications that has reached and unreached the user out of the total publications were identified and their percentages were shown in Table 3 along with Reach \%, RAI, URAI and UAI.

Table 3 Reached Vs Unreached publications of IIMs

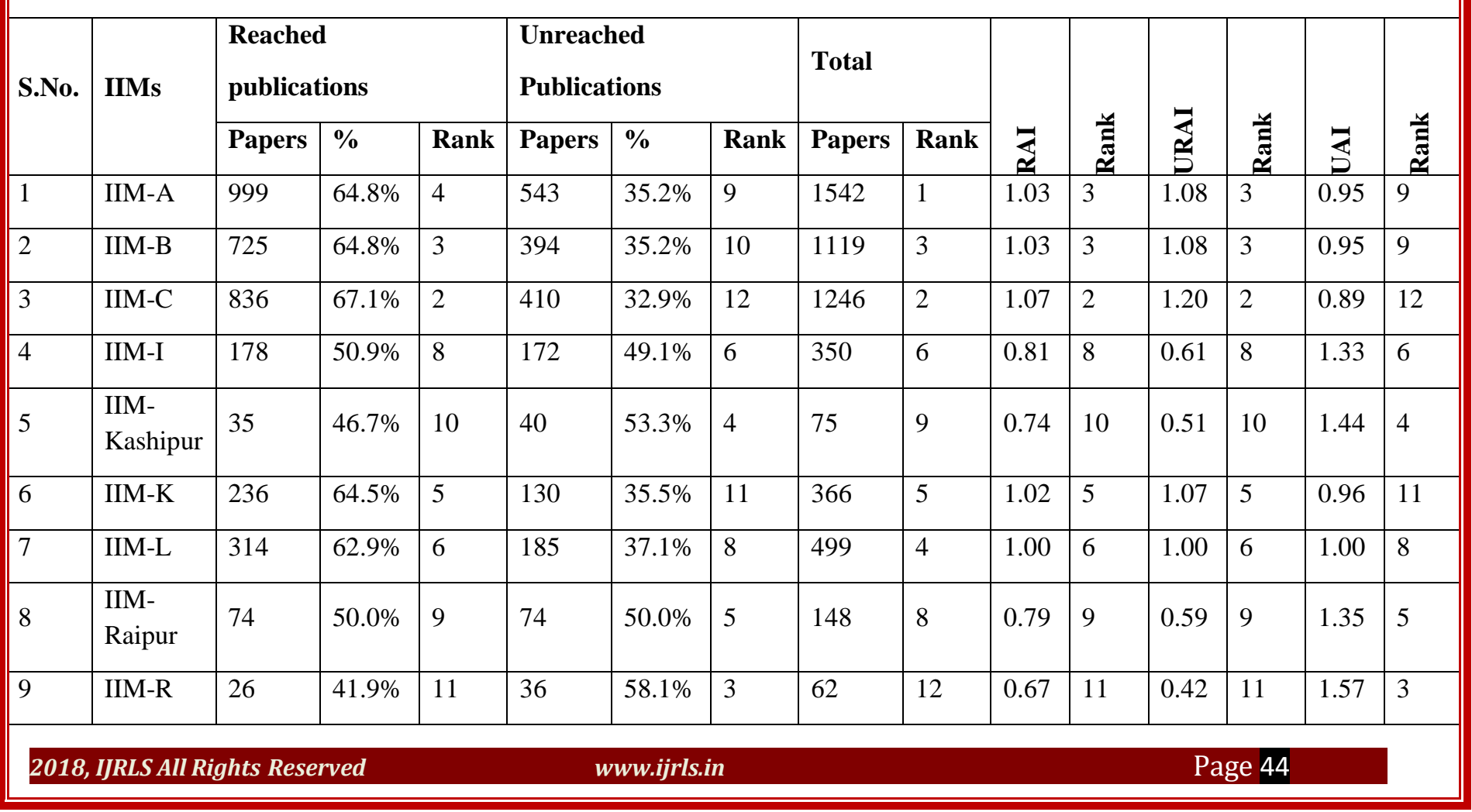


Tamizhchelvan, M \& Gopalakrishnan, $S$

\begin{tabular}{|l|l|l|l|l|l|l|l|l|l|l|l|l|l|l|l||}
\hline 10 & $\begin{array}{l}\text { IIM- } \\
\text { Rohtak }\end{array}$ & 117 & $68.0 \%$ & 1 & 55 & $32.0 \%$ & 13 & 172 & 7 & 1.08 & 1 & 1.25 & 1 & 0.86 & 13 \\
\hline 11 & IIM-S & 40 & $60.6 \%$ & 7 & 26 & $39.4 \%$ & 7 & 66 & 10 & 0.96 & 7 & 0.90 & 7 & 1.06 & 7 \\
\hline 12 & IIM-T & 18 & $40.9 \%$ & 12 & 26 & $59.1 \%$ & 2 & 44 & 13 & 0.65 & 13 & 0.41 & 13 & 1.60 & 1 \\
\hline 13 & IIM-U & 27 & $40.9 \%$ & 13 & 39 & $59.1 \%$ & 1 & 66 & 11 & 0.65 & 13 & 0.41 & 13 & 1.60 & 1 \\
\hline Total & & $\mathbf{3 6 2 5}$ & $\mathbf{6 3 . 0} \%$ & & $\mathbf{2 1 3 0}$ & $\mathbf{3 7 . 0 \%}$ & & $\mathbf{5 7 5 5}$ & & $\mathbf{1 . 0 0}$ & & $\mathbf{1 . 0 0}$ & & & \\
\hline
\end{tabular}

(RAI - Reach Activity Index; URAI - Unreach / Reach Activity Index; UAI - Unreach Activity Index)

UAI of publications ranges between 0.86 and 1.60. IIM- T and IIM-U were positioned first in the unreach of their publications. It is followed by IIM-R positioned third; IIM-Kashipur positioned fourth and IIM-Raipur were positioned fifth unreach of publications.

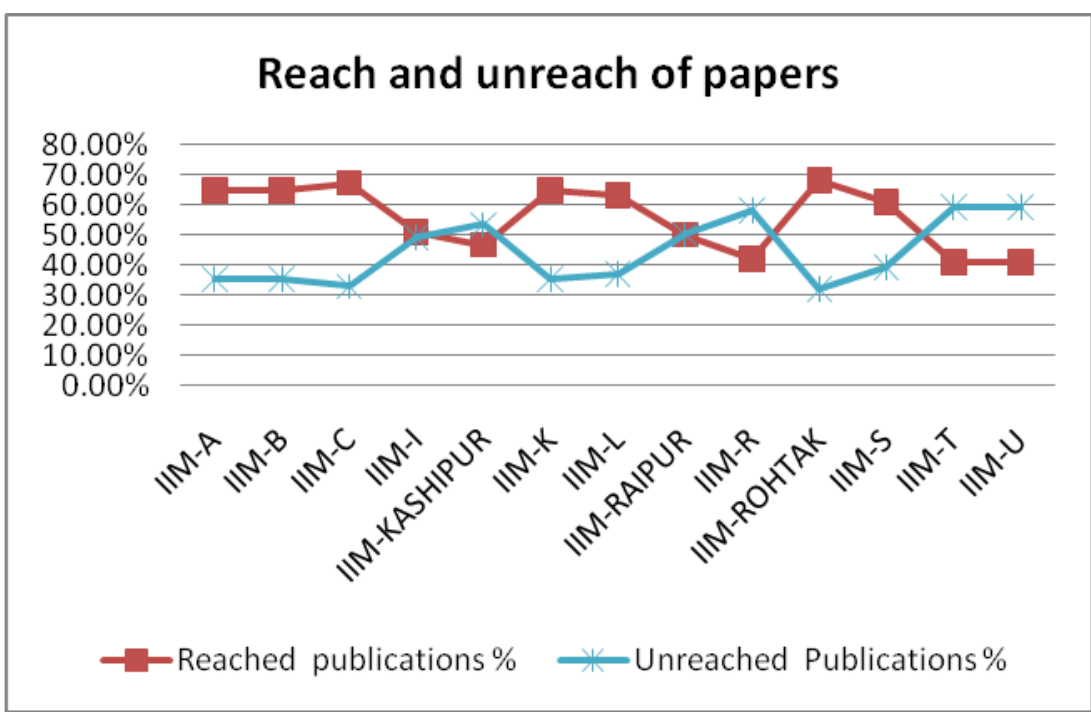

Figure 1 Reach and Unreach of papers

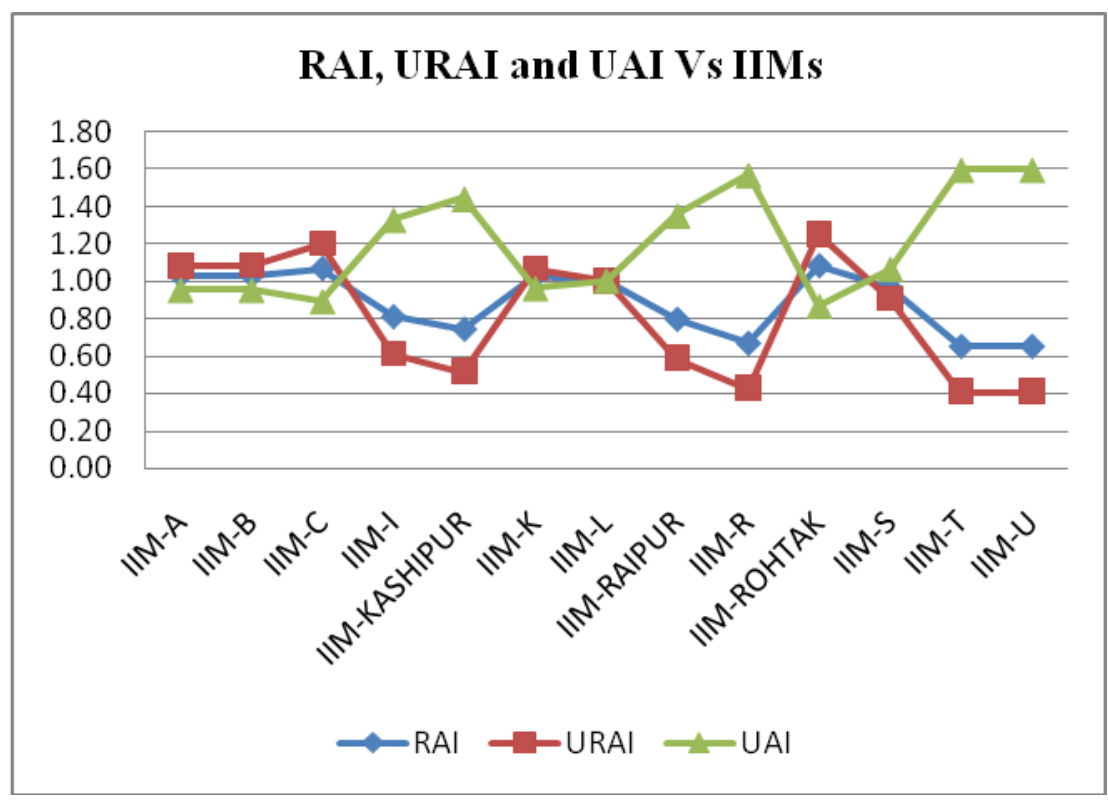

Figure 2 RAI, URAI and UAI Vs IIMs 
Based on total publications IIM-A centre has highest number of publications (1542). It is followed by IIM-C (1246); IIM-B (1119) and IIM-L (499). Least number of publications can be seen in IIM-T (44); IIM-R (62) ; IIM-S (66) and IIM-U (66). Nearly $40.9 \%$ to $68 \%$ of individual centre publications were reached the user. The ranks were assigned based on the percentage of the publications that has reached of particular centres. Accordingly IIM-Rohtak has $68 \%$ of their publications were reached the user. It is followed by IIM-C (67.1\%); IIM-B (64.8\%) and IIM-A (64.8\%). The unreached publications were ranging between $59.1 \%$ and $32.0 \%$. Unreached publications were more in IIM-U (59.1\%); IIM-T (59.1\%); IIM-R (58.1\%) and IIM-Raipur $(50.0 \%)$. Least unreached publications were from IIM-Rohtak (32.0\%) and IIM-C (32.9\%).

The RAI ranges between 0.65 and 1.08. IIM-Rohtak were ranked first in the reach of their publications even the number of publications were positioned seventh place in total number of papers. It is followed by IIM-C positioned second and IIM-B and IIM-A were positioned third even thou the number of publications were more.

URAI of publications ranges between 0.41 and 1.08. IIM- Rohtak were ranked first in the unreach/reach of their publications even the number of publications. It is followed by IIM-C positioned second and IIM-B and IIM-A were positioned third even though the number of publications were more. IIM-T and IIM-U were least in reach of publications.

UAI of publications ranges between 0.86 and 1.60. IIM- T and IIM-U were positioned first in the unreach of their publications. It is followed by IIM-R positioned third; IIM-Kashipur positioned fourth and IIM-Raipur were positioned fifth unreach of publications.

The ranks derived through the four methods were identical. Hence the methods, adopted to identify the reach were verified.

The yearwise distribution of reach of articles were identified and the same has been shown in Table 3 
Table 3 Reach of articles - Yearwise

\begin{tabular}{|c|c|c|c|c|c|c|c|c|c|c|}
\hline \multirow[t]{2}{*}{ S.No } & \multirow[t]{2}{*}{ Year } & \multicolumn{2}{|c|}{$\begin{array}{l}\text { Reached } \\
\text { publications }\end{array}$} & \multicolumn{2}{|c|}{$\begin{array}{l}\text { Un Reached } \\
\text { Publications }\end{array}$} & \multicolumn{2}{|c|}{ Total Publications } & \multirow[t]{2}{*}{ RAI } & \multirow[t]{2}{*}{ URAI } & \multirow[t]{2}{*}{ UAI } \\
\hline & & Papers & $\%$ & Papers & $\%$ & Papers & $\%$ & & & \\
\hline 1 & 1965 & 1 & $50.0 \%$ & 1 & $50.0 \%$ & 2 & $100.0 \%$ & 0.79 & 0.59 & 1.35 \\
\hline 2 & 1966 & 3 & $75.0 \%$ & 1 & $25.0 \%$ & 4 & $100.0 \%$ & 1.19 & 1.76 & 0.68 \\
\hline 3 & 1967 & 1 & $50.0 \%$ & 1 & $50.0 \%$ & 2 & $100.0 \%$ & 0.79 & 0.59 & 1.35 \\
\hline 4 & 1968 & 3 & $75.0 \%$ & 1 & $25.0 \%$ & 4 & $100.0 \%$ & 1.19 & 1.76 & 0.68 \\
\hline 5 & 1969 & 2 & $50.0 \%$ & 2 & $50.0 \%$ & 4 & $100.0 \%$ & 0.79 & 0.59 & 1.35 \\
\hline 6 & 1970 & 3 & $75.0 \%$ & 1 & $25.0 \%$ & 4 & $100.0 \%$ & 1.19 & 1.76 & 0.68 \\
\hline 7 & 1971 & 5 & $100.0 \%$ & 0 & $.0 \%$ & 5 & $100.0 \%$ & 1.59 & 0.00 & 0.00 \\
\hline 8 & 1972 & 3 & $100.0 \%$ & 0 & $.0 \%$ & 3 & $100.0 \%$ & 1.59 & 0.00 & 0.00 \\
\hline 9 & 1973 & 4 & $57.1 \%$ & 3 & $42.9 \%$ & 7 & $100.0 \%$ & 0.91 & 0.78 & 1.16 \\
\hline 10 & 1974 & 6 & $85.7 \%$ & 1 & $14.3 \%$ & 7 & $100.0 \%$ & 1.36 & 3.53 & 0.39 \\
\hline 11 & 1975 & 4 & $100.0 \%$ & 0 & $.0 \%$ & 4 & $100.0 \%$ & 1.59 & 0.00 & 0.00 \\
\hline 12 & 1976 & 10 & $83.3 \%$ & 2 & $16.7 \%$ & 12 & $100.0 \%$ & 1.32 & 2.94 & 0.45 \\
\hline 13 & 1977 & 7 & $87.5 \%$ & 1 & $12.5 \%$ & 8 & $100.0 \%$ & 1.39 & 4.11 & 0.34 \\
\hline 14 & 1978 & 7 & $77.8 \%$ & 2 & $22.2 \%$ & 9 & $100.0 \%$ & 1.23 & 2.06 & 0.60 \\
\hline 15 & 1979 & 7 & $87.5 \%$ & 1 & $12.5 \%$ & 8 & $100.0 \%$ & 1.39 & 4.11 & 0.34 \\
\hline 16 & 1980 & 9 & $75.0 \%$ & 3 & $25.0 \%$ & 12 & $100.0 \%$ & 1.19 & 1.76 & 0.68 \\
\hline 17 & 1981 & 11 & $78.6 \%$ & 3 & $21.4 \%$ & 14 & $100.0 \%$ & 1.25 & 2.15 & 0.58 \\
\hline 18 & 1982 & 6 & $42.9 \%$ & 8 & $57.1 \%$ & 14 & $100.0 \%$ & 0.68 & 0.44 & 1.54 \\
\hline 19 & 1983 & 13 & $65.0 \%$ & 7 & $35.0 \%$ & 20 & $100.0 \%$ & 1.03 & 1.09 & 0.95 \\
\hline 20 & 1984 & 5 & $41.7 \%$ & 7 & $58.3 \%$ & 12 & $100.0 \%$ & 0.66 & 0.42 & 1.58 \\
\hline 21 & 1985 & 14 & $93.3 \%$ & 1 & $6.7 \%$ & 15 & $100.0 \%$ & 1.48 & 8.23 & 0.18 \\
\hline 22 & 1986 & 12 & $60.0 \%$ & 8 & $40.0 \%$ & 20 & $100.0 \%$ & 0.95 & 0.88 & 1.08 \\
\hline 23 & 1987 & 9 & $42.9 \%$ & 12 & $57.1 \%$ & 21 & $100.0 \%$ & 0.68 & 0.44 & 1.54 \\
\hline 24 & 1988 & 10 & $90.9 \%$ & 1 & $9.1 \%$ & 11 & $100.0 \%$ & 1.44 & 5.88 & 0.25 \\
\hline 25 & 1989 & 10 & $66.7 \%$ & 5 & $33.3 \%$ & 15 & $100.0 \%$ & 1.06 & 1.18 & 0.90 \\
\hline 26 & 1990 & 12 & $75.0 \%$ & 4 & $25.0 \%$ & 16 & $100.0 \%$ & 1.19 & 1.76 & 0.68 \\
\hline 27 & 1991 & 11 & $64.7 \%$ & 6 & $35.3 \%$ & 17 & $100.0 \%$ & 1.03 & 1.08 & 0.95 \\
\hline 28 & 1992 & 20 & $87.0 \%$ & 3 & $13.0 \%$ & 23 & $100.0 \%$ & 1.38 & 3.92 & 0.35 \\
\hline 29 & 1993 & 23 & $88.5 \%$ & 3 & $11.5 \%$ & 26 & $100.0 \%$ & 1.40 & 4.50 & 0.31 \\
\hline 30 & 1994 & 21 & $70.0 \%$ & 9 & $30.0 \%$ & 30 & $100.0 \%$ & 1.11 & 1.37 & 0.81 \\
\hline 31 & 1995 & 23 & $76.7 \%$ & 7 & $23.3 \%$ & 30 & $100.0 \%$ & 1.22 & 1.93 & 0.63 \\
\hline
\end{tabular}




\begin{tabular}{|c|c|c|c|c|c|c|c|c|c|c|}
\hline 32 & 1996 & 38 & $77.6 \%$ & 11 & $22.4 \%$ & 49 & $100.0 \%$ & 1.23 & 2.03 & 0.61 \\
\hline 33 & 1997 & 39 & $67.2 \%$ & 19 & $32.8 \%$ & 58 & $100.0 \%$ & 1.07 & 1.21 & 0.89 \\
\hline 34 & 1998 & 40 & $65.6 \%$ & 21 & $34.4 \%$ & 61 & $100.0 \%$ & 1.04 & 1.12 & 0.93 \\
\hline 35 & 1999 & 48 & $72.7 \%$ & 18 & $27.3 \%$ & 66 & $100.0 \%$ & 1.15 & 1.57 & 0.74 \\
\hline 36 & 2000 & 50 & $73.5 \%$ & 18 & $26.5 \%$ & 68 & $100.0 \%$ & 1.17 & 1.63 & 0.72 \\
\hline 37 & 2001 & 57 & $75.0 \%$ & 19 & $25.0 \%$ & 76 & $100.0 \%$ & 1.19 & 1.76 & 0.68 \\
\hline 38 & 2002 & 59 & $70.2 \%$ & 25 & $29.8 \%$ & 84 & $100.0 \%$ & 1.12 & 1.39 & 0.80 \\
\hline 39 & 2003 & 94 & $84.7 \%$ & 17 & $15.3 \%$ & 111 & $100.0 \%$ & 1.34 & 3.25 & 0.41 \\
\hline 40 & 2004 & 94 & $77.0 \%$ & 28 & $23.0 \%$ & 122 & $100.0 \%$ & 1.22 & 1.97 & 0.62 \\
\hline 41 & 2005 & 98 & $77.8 \%$ & 28 & $22.2 \%$ & 126 & $100.0 \%$ & 1.23 & 2.06 & 0.60 \\
\hline 42 & 2006 & 115 & $79.9 \%$ & 29 & $20.1 \%$ & 144 & $100.0 \%$ & 1.27 & 2.33 & 0.54 \\
\hline 43 & 2007 & 119 & $79.9 \%$ & 30 & $20.1 \%$ & 149 & $100.0 \%$ & 1.27 & 2.33 & 0.54 \\
\hline 44 & 2008 & 146 & $77.2 \%$ & 43 & $22.8 \%$ & 189 & $100.0 \%$ & 1.23 & 2.00 & 0.61 \\
\hline 45 & 2009 & 169 & $74.4 \%$ & 58 & $25.6 \%$ & 227 & $100.0 \%$ & 1.18 & 1.71 & 0.69 \\
\hline 46 & 2010 & 176 & $78.6 \%$ & 48 & $21.4 \%$ & 224 & $100.0 \%$ & 1.25 & 2.15 & 0.58 \\
\hline 47 & 2011 & 225 & $78.9 \%$ & 60 & $21.1 \%$ & 285 & $100.0 \%$ & 1.25 & 2.20 & 0.57 \\
\hline 48 & 2012 & 260 & $77.6 \%$ & 75 & $22.4 \%$ & 335 & $100.0 \%$ & 1.23 & 2.04 & 0.60 \\
\hline 49 & 2013 & 265 & $77.0 \%$ & 79 & $23.0 \%$ & 344 & $100.0 \%$ & 1.22 & 1.97 & 0.62 \\
\hline 50 & 2014 & 288 & $73.1 \%$ & 106 & $26.9 \%$ & 394 & $100.0 \%$ & 1.16 & 1.60 & 0.73 \\
\hline 51 & 2015 & 325 & $67.7 \%$ & 155 & $32.3 \%$ & 480 & $100.0 \%$ & 1.07 & 1.23 & 0.87 \\
\hline 52 & 2016 & 320 & $57.0 \%$ & 241 & $43.0 \%$ & 561 & $100.0 \%$ & 0.91 & 0.78 & 1.16 \\
\hline 53 & 2017 & 245 & $37.5 \%$ & 408 & $62.5 \%$ & 653 & $100.0 \%$ & 0.60 & 0.35 & 1.69 \\
\hline 54 & 2018 & 80 & $14.0 \%$ & 490 & $86.0 \%$ & 570 & $100.0 \%$ & 0.22 & 0.10 & 2.32 \\
\hline \multicolumn{2}{|c|}{ Total } & 3625 & $63.0 \%$ & 2130 & $37.0 \%$ & 5755 & $100.0 \%$ & 1.00 & 1.00 & 1.00 \\
\hline
\end{tabular}

(RAI-Reach Activity Index; URAI - Unreach / Reach Activity Index; UAI - Unreach Activity Index)

The RAI ranges between 0.22 and 1.59. Maximum RAI were can be seen in the year 1971, 1972 and 1975. RAI were below one only in eleven years out of the 54 years study period. It can be inferred that the IIM publications of 43 years were reached the users.

URAI of publications ranges between 0.10 and 8.23. Maximum RAI can be seen during the year 1985 . It is followed by 5.88 during the year 1988; 4.50 in the year 1993 and 4.11 in 1977 and 1979. This indicates the publications in the indicated in the year were used maximum.

UAI of publications ranges between 0.00 and 2.32. The maximum UAI can be seen in the year 2018 (2.32); 1.69 (2017) and 1.58 (1984). Only eleven years of publications were unreached to the users.

It can be inferred that the majority of the IIM publications were reached the user. 


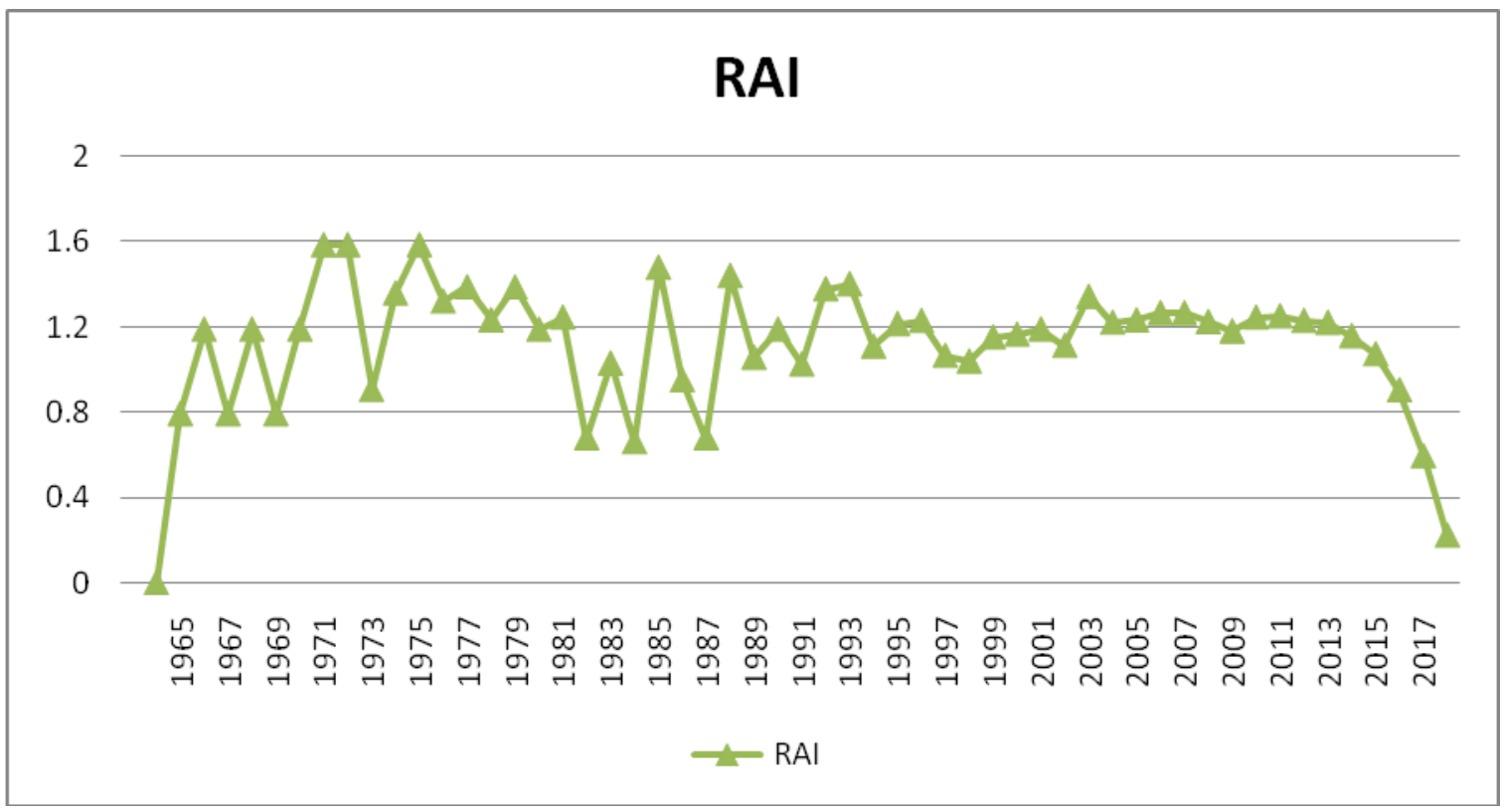

Figure 3 Reach Activity Index

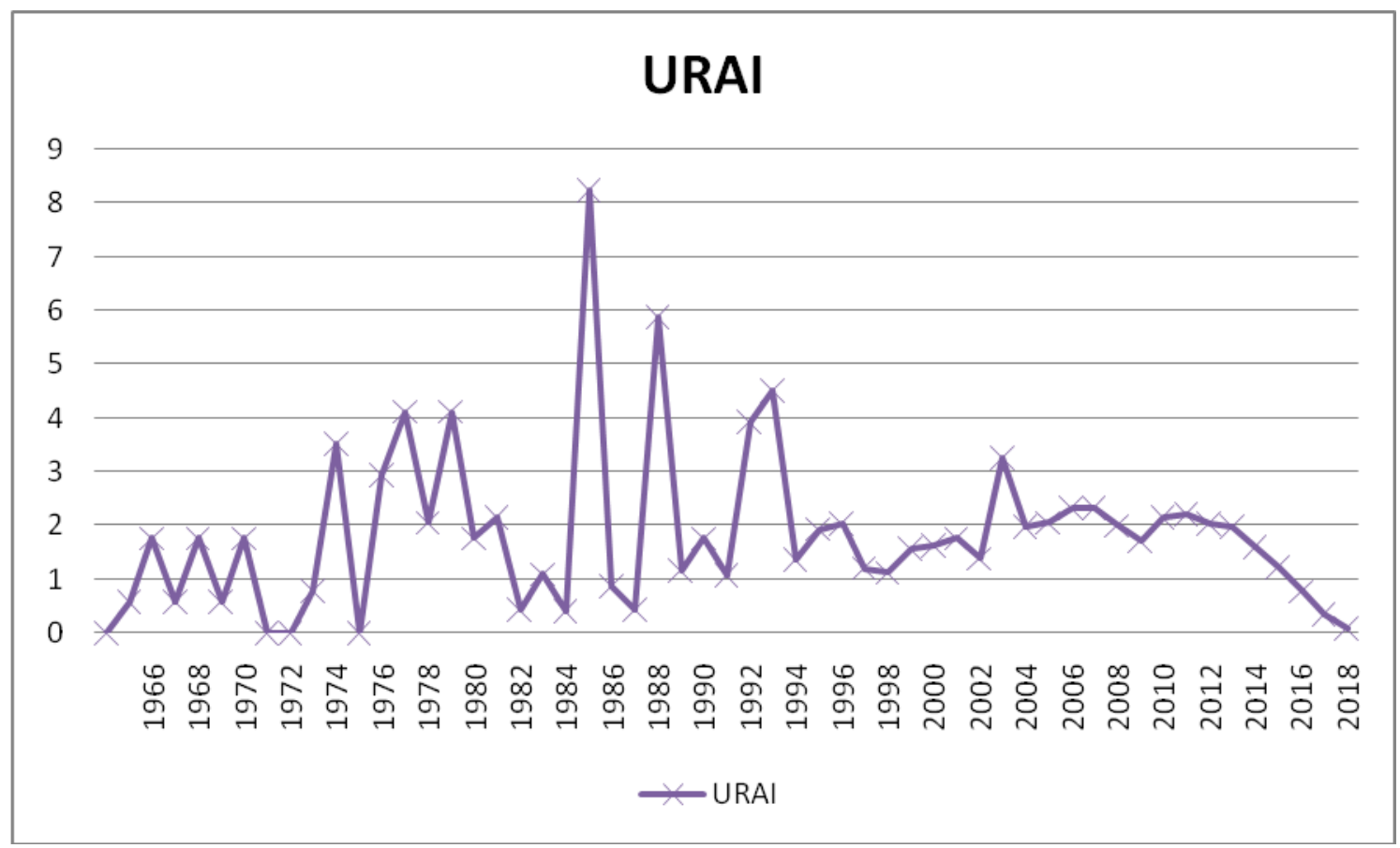

Figure 4 Unreach/Reach Activity Index 


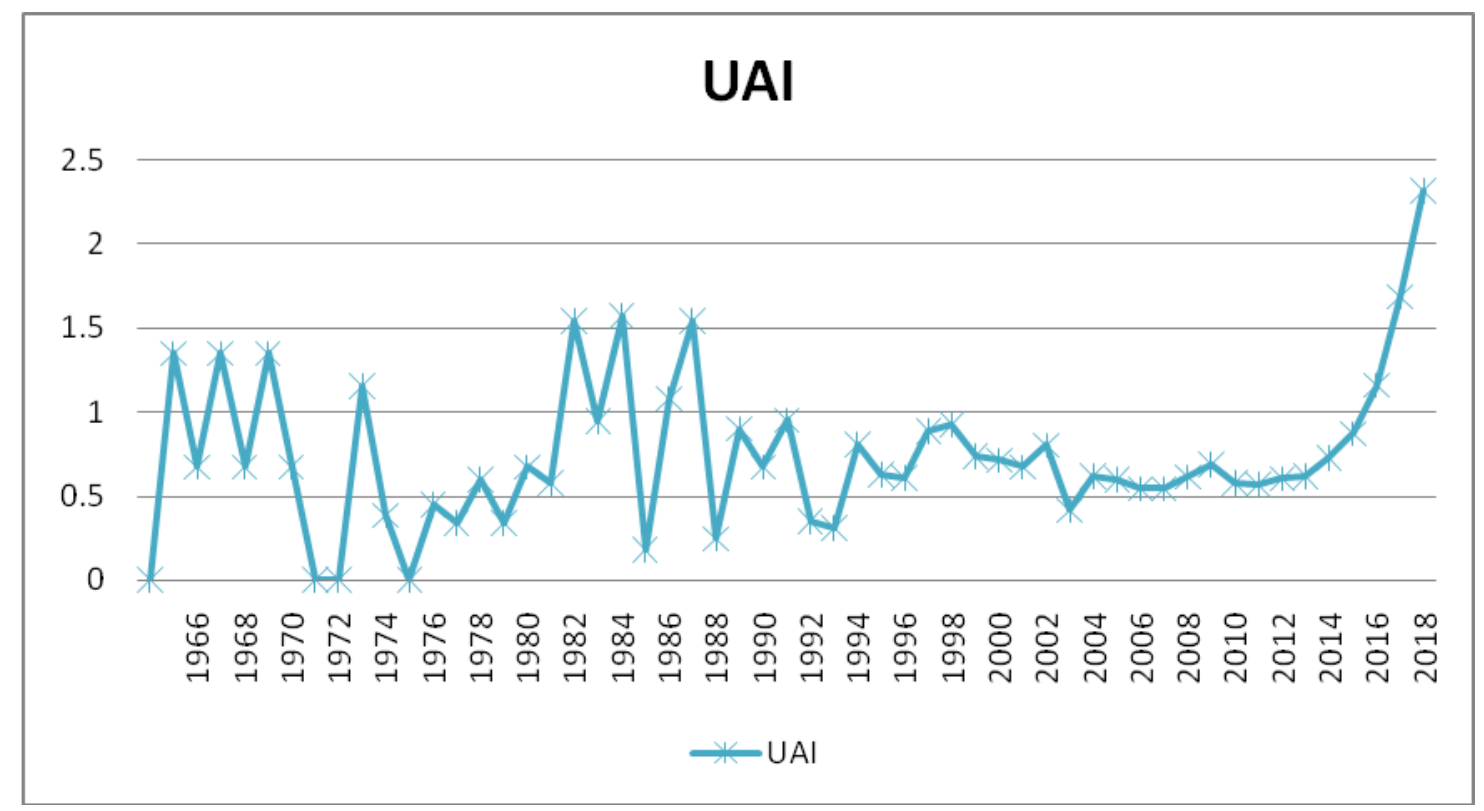

Figure 5 Unreach Activity Index

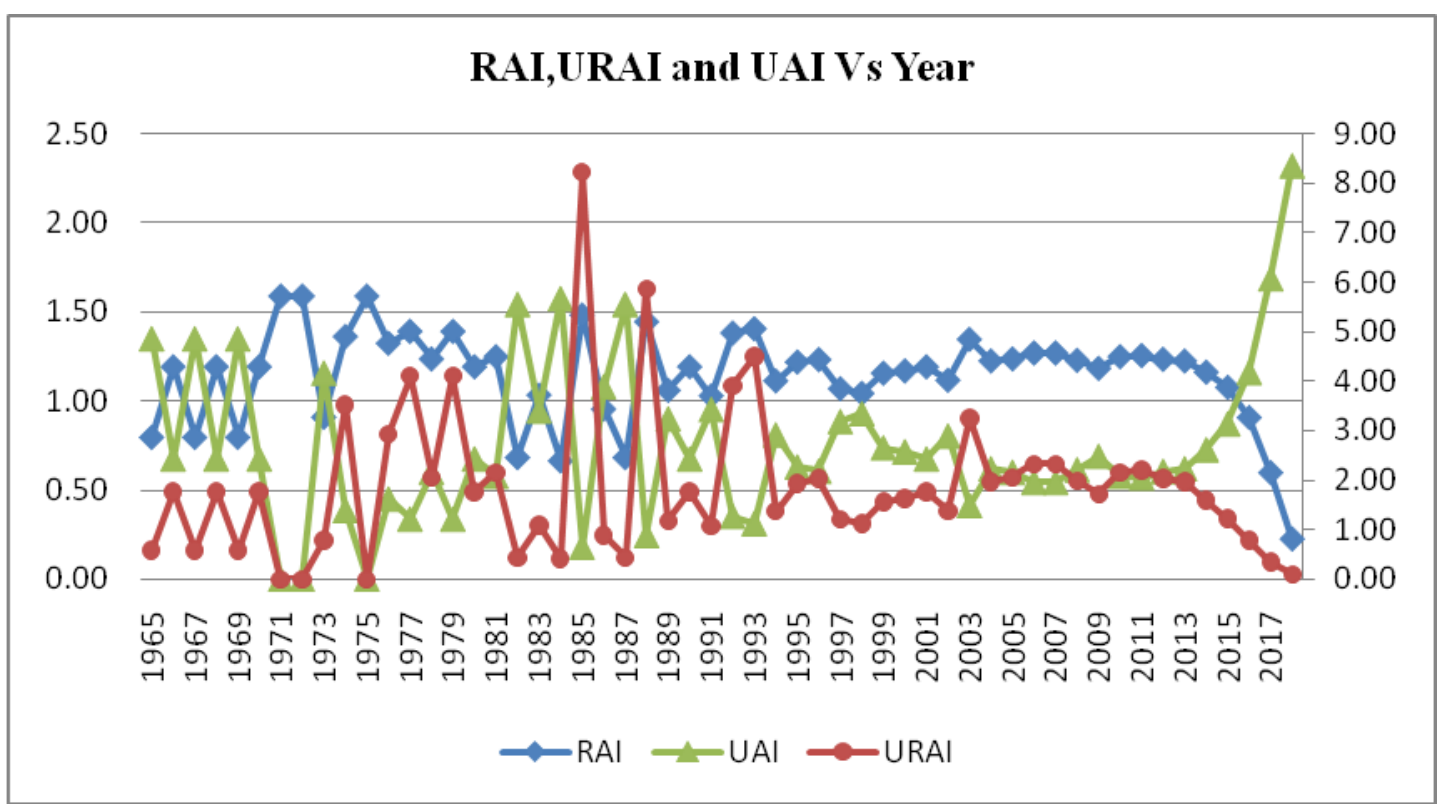

Figure 6 RAI, URAI and UAI Vs Year

The percentile of reach publications ranges between $14.0 \%$ and $100 \%$. Similarly unreached publications percentile ranges between $0.0 \%$ and $86.0 \%$. All the publications that were published in the year 1971,1972 and 1975 were reached the user. During the period 1999 and 2014, more than $70 \%$ of publications were reached the user.

The authorship pattern of reached publications were analysed and the same has been shown in Table 4

Table 4 Authorship pattern of Reached publications

\begin{tabular}{|l|l|l|l|l|l|l|l|l|l|l|}
\hline \multirow{2}{*}{ S.No. } & \multirow{2}{*}{$\begin{array}{l}\text { Authorship } \\
\text { pattern }\end{array}$} & \multicolumn{2}{|l|}{ Reached } & \multicolumn{2}{|l|}{ Unreached } & \multicolumn{2}{|l|}{ Total } & \multirow{2}{*}{ RAI } & \multirow{2}{*}{ URAI } & \multirow{2}{*}{ UAI } \\
\cline { 3 - 9 } & Papers & $\%$ & Papers & $\%$ & Papers & $\%$ & & & \\
\hline 1 & Single author & 882 & $56.5 \%$ & 678 & $43.5 \%$ & 1560 & $100.0 \%$ & 0.90 & 0.76 & 1.17 \\
\hline
\end{tabular}


Tamizhchelvan, M \& Gopalakrishnan, $S$

\begin{tabular}{|l|l|l|l|l|l|l|l|l|l|l|}
\hline 2 & Two author & 1377 & $64.9 \%$ & 746 & $35.1 \%$ & 2123 & $100.0 \%$ & 1.03 & 1.08 & 0.95 \\
\hline 3 & Three author & 815 & $65.0 \%$ & 439 & $35.0 \%$ & 1254 & $100.0 \%$ & 1.03 & 1.09 & 0.95 \\
\hline 4 & Four author & 321 & $67.4 \%$ & 155 & $32.6 \%$ & 476 & $100.0 \%$ & 1.07 & 1.22 & 0.88 \\
\hline 5 & Five author & 110 & $64.3 \%$ & 61 & $35.7 \%$ & 171 & $100.0 \%$ & 1.02 & 1.06 & 0.96 \\
\hline 6 & Six and above & 120 & $70.2 \%$ & 51 & $29.8 \%$ & 171 & $100.0 \%$ & 1.11 & 1.38 & 0.81 \\
\hline Total & & $\mathbf{3 6 2 5}$ & $\mathbf{6 3 . 0 \%}$ & $\mathbf{2 1 3 0}$ & $\mathbf{3 7 . 0 \%}$ & $\mathbf{5 7 5 5}$ & $\mathbf{1 0 0 . 0} \%$ & $\mathbf{1 . 0 0}$ & $\mathbf{1 . 0 0}$ & $\mathbf{1 . 0 0}$ \\
\hline
\end{tabular}

(RAI-Reach Activity Index; URAI-Unreach/Reach Activity Index; UAI-Unreach Activity Index)

The RAI for authorship pattern ranges between 0.90 and 1.18. Six and above authors publications were highest RAI (1.11) which indicates that these publications were reached the user. It is followed by four authors (1.07); three authors and two authors (1.03). Single author publications were not reaching the user. This indicates that collaborative reach paper were reaching the users substantially.

URAI of authorship pattern publications ranges between 0.76 and 1.38 . RAI and URAI shows identical in the research output.

UAI of authorship pattern publications ranges between 0.81 and 1.17 . The unreach of the publications were below one in all authorship pattern except single author publications.

The inference derived through the four methods, were identical. Hence the methods adopted to identify the reach were verified.

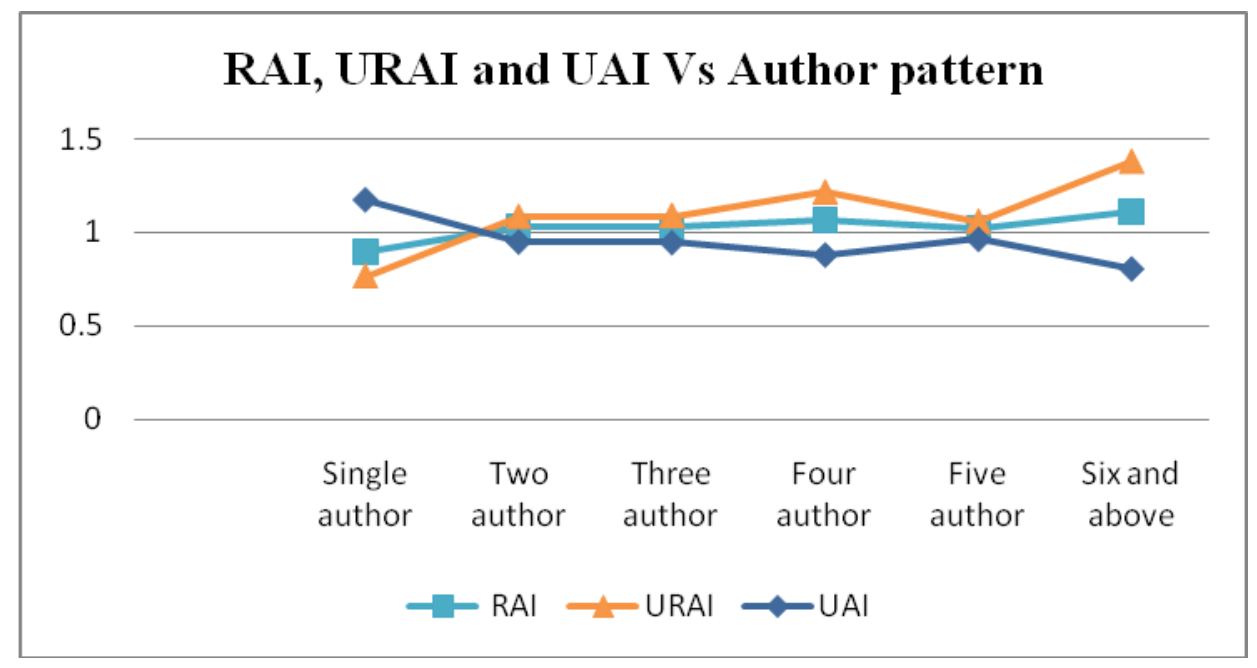

Figure 7 RAI, URAI and UAI Vs Authorship Pattern

The study has further been extended institutions and authorship pattern and the same has been shown in Table 5 . 
Table 5 Reached publications Vs Authorship pattern

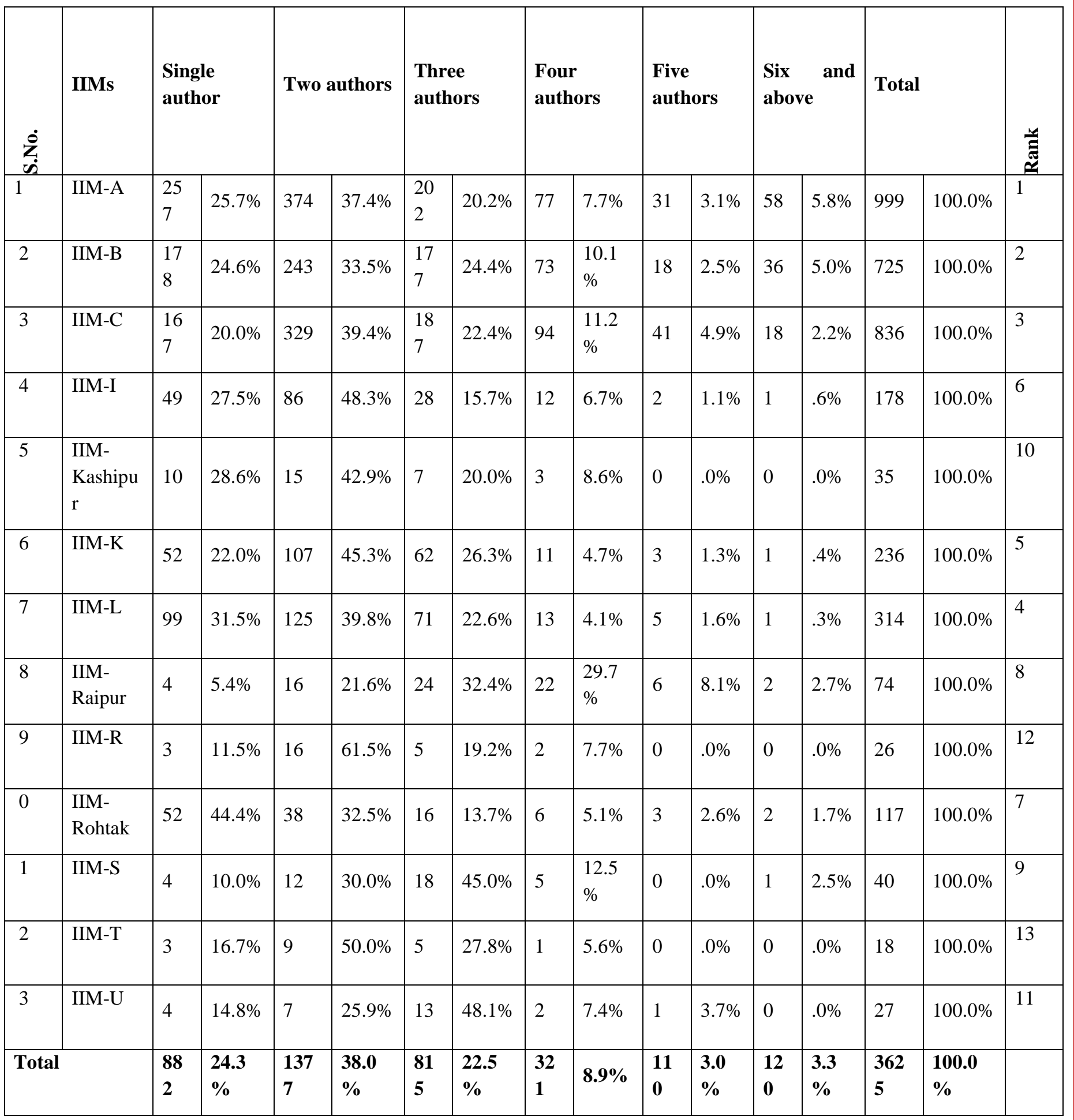

IIM -A has been ranked first in the authorship pattern. It is followed by IIM-B; IIM-C and IIM-L. RAI for the same has been calculated and shown in Table 6. 
Table 6 RAI Vs Authorship pattern

\begin{tabular}{|c|c|c|c|c|c|c|c|c|c|c|c|c|c|c|}
\hline S.No. & IIMs & $\begin{array}{l}\stackrel{0}{00} \\
\stackrel{0}{=}\end{array}$ & $\underset{\pi}{2}$ & 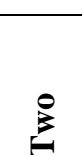 & 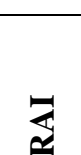 & 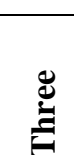 & 赵 & ఏే & $\sum$ & $\stackrel{\Xi}{z}$ & $\overline{2}$ & $\stackrel{\infty}{\infty}$ & $\underset{2}{\simeq}$ & పే \\
\hline 1 & IIM-A & 257 & 1.06 & 374 & 0.99 & 202 & 0.90 & 77 & 0.87 & 31 & 1.02 & 58 & 1.75 & 999 \\
\hline 2 & IIM-B & 178 & 1.01 & 243 & 0.88 & 177 & 1.09 & 73 & 1.14 & 18 & 0.82 & 36 & 1.50 & 725 \\
\hline 3 & IIM-C & 167 & 0.82 & 329 & 1.04 & 187 & 0.99 & 94 & 1.27 & 41 & 1.62 & 18 & 0.65 & 836 \\
\hline 4 & IIM-I & 49 & 1.13 & 86 & 1.27 & 28 & 0.70 & 12 & 0.76 & 2 & 0.37 & 1 & 0.17 & 178 \\
\hline 5 & IIM-Kashipur & 10 & 1.17 & 15 & 1.13 & 7 & 0.89 & 3 & 0.97 & 0 & 0.00 & 0 & 0.00 & 35 \\
\hline 6 & IIM-K & 52 & 0.91 & 107 & 1.19 & 62 & 1.17 & 11 & 0.53 & 3 & 0.42 & 1 & 0.13 & 236 \\
\hline 7 & IIM-L & 99 & 1.30 & 125 & 1.05 & 71 & 1.01 & 13 & 0.47 & 5 & 0.52 & 1 & 0.10 & 314 \\
\hline 8 & IIM-Raipur & 4 & 0.22 & 16 & 0.57 & 24 & 1.44 & 22 & 3.36 & 6 & 2.67 & 2 & 0.82 & 74 \\
\hline 9 & IIM-R & 3 & 0.47 & 16 & 1.62 & 5 & 0.86 & 2 & 0.87 & 0 & 0.00 & 0 & 0.00 & 26 \\
\hline 10 & IIM-Rohtak & 52 & 1.83 & 38 & 0.86 & 16 & 0.61 & 6 & 0.58 & 3 & 0.84 & 2 & 0.52 & 117 \\
\hline 11 & IIM-S & 4 & 0.41 & 12 & 0.79 & 18 & 2.00 & 5 & 1.41 & 0 & 0.00 & 1 & 0.76 & 40 \\
\hline 12 & IIM-T & 3 & 0.68 & 9 & 1.32 & 5 & 1.24 & 1 & 0.63 & 0 & 0.00 & 0 & 0.00 & 18 \\
\hline 13 & IIM-U & 4 & 0.61 & 7 & 0.68 & 13 & 2.14 & 2 & 0.84 & 1 & 1.22 & 0 & 0.00 & 27 \\
\hline \multicolumn{2}{|l|}{ Total } & 882 & 1.00 & 1377 & 1.00 & 815 & 1.00 & 321 & 1.00 & 110 & 1.00 & 120 & 1.00 & 3625 \\
\hline
\end{tabular}

(RAI- Reach Activity Index)

\section{CONCLUSION}

The present study on measure of reach of scientific publications of Indian institute of Management institutions scientific output has implications a large proportion of their publications were reached the users. This study will pave way to enhance the quality of the papers they publish. Further method has been designed to identify the type of the unreached papers. It cannot be said that unreached papers are not being used and do not contribute to scientific progress. Here the author introduced an indicator called as RAI, URAI, and UAI which are calculated in a way similar Relative Uncitedness Index (RUI) by Garg and S. Kumar and to Relative Citation Impact (RCI) used by Kumari (2009) in a study on synthetic organic chemistry research. The present study enables to derive a methodology to measure the reach of the publications among the users using Reach Activity Index, Unreach/Reach Activity Index, Unreach Activity Index and Reach percentage. Similar studies may be undertaken for other R \& D organization, subject areas in order to identify the worthiness of measurement technique suggest in this study.

\section{REFERENCES}

[1]. Abramo, G., Cicero, T., \& D'Angelo, C. A. (2014). Are the authors of highly cited articles also the most productive ones? Journal of Informetrics, 8(1): 89-97.

[2]. Bathrinarayanan, AL and Tamizhchelvan, M, (2103), MEMS output in Scopus database: A Bibliometric Analysis, Journal of Advances in Library and Information Science, 2(2): 100-104.

[3]. Bornmann, L. (2014). How are excellent (highly cited) papers defined in bibliometrics? A quantitative analysis of the literature. Research Evaluation, 23(2):166-173.

[4]. Cronin, B. (1984). The Citation Process. The Role and Significance of Citations in Scientific Communication, 103p. Taylor Graham, Oxford.

[5]. Dwivedi, Sandhya (2016). Scientometric analysis of Cognitive Neuroscience Research Literature: 2006-2015, International Journal Research in Library Science, 2(2): 1-8.

[6]. Garg, K. C. and S. Kumar (2014), Uncitedness of Indian scientific output, Current Science, 107(6): 966.

[7]. Gopalakrishnan, S, Gopalakrishnan, S, Bathrinaryanan, AL and Tamizhchelvan, M, Uncited Publications in MEMS Literature: A Bibliometric Study. DESIDOC Journal of Library \& Information Technology, 2015, 35(2):. $113-123$.

[8]. Kumari, G. L (2009). Synthetic organic chemistry research: analysis by scientometric indicators. Scientometrics, 80(3), 559570 .

[9]. Leydesdorff, L. (2012). Alternatives to the journal impact factor: I3 and the top-10\% (or top-25\%?) of the most-highly cited papers. Scientometrics, 92(2): 355-365. 
[10]. Persson, O. (2010). Are highly cited papers more international? Scientometrics, 83(2): 397-401.

[11]. Petr Heneberg, (2013), Supposedly uncited articles of Nobel laureates and Fields medalists can be prevalently attributed to the errors of omission and commission, Journal of the Association for Information Science and Technology, 64(3): 448454.

[12]. Petr Heneberg, (2014), Parallel worlds of citable documents and others: Inflated commissioned opinion articles enhance scientometric indicators, Journal of the Association for Information Science and Technology, 65 (3): $635-643$.

[13]. Vaijinath, S. Birangal and Shivashankar, Ghumre, (2017), Bibliometrics analysis of DJLIT with special reference to productivity patterns of Authors from beginning to 2015, International Journal of Research in Library Science, 3(1): 66-73.

[14]. Van Noorden, R., Maher, B., \& Nuzzo, R. (2014). The Top-100 papers. Nature, 514(7524): 550-553. 